\title{
NON-EXISTING TSERKVAS AS UKRAINIAN CULTURAL HERITAGE IN SACRAL LANDSCAPE IN SOLYNA COMMUNE
}

\author{
'Hanna KOZAK, ${ }^{2}$ Ihor KOZAK \\ 1,2 John Paul II Catholic University of Lublin, Poland \\ 'hannakozak@kul.lublin.pl
}

\begin{abstract}
The article presents the non-existing tserkvas in sacred landscape in Solyna commune (in the Polish-Ukrainian borderland). These tserkvas represent 20 sacral objects with the architectural specificity of the Ukrainian national wooden and stone tserkva. History of non-existing tserkvas in the landscape of Solyna commune has been analyzed. In particular, there was noted the uniqueness of the Ukrainian tserkva, the technique of "zrub" and elements of "zalom" in Ukrainian architecture. This aspect integrate Ukrainian tserkvas, which vary only in terms proportions in length, width and height. Ukrainian tserkvas in Solyna commune were destroyed after the mass deportation of Ukrainian ethnic population from their land after the year 1947. Tserkvas lost the religious, cultural and national role and sacred landscape lost its meaning. Non-existing tserkvas (20) occupy almost $100 \%$ of all the tserkvas in the study area. The article shows the specificity of Ukrainian wooden and stone tserkvas architecture. Two tserkvas were destroyed in the years 1945-1947 in Tyskova and Radeva. Four tserkvas were destroyed after the years 1945-1947 in Bukovets, Studenne, Ralske and Berezhnytsya Dolishnya. Five tserkvas were disassembled in the postwar period in Solyna, Berezka, Horodok, Terka, Vovkovyja. Three tserkvas were destroyed in the postwar period in Zaviz, Bibrka, Volya Matyasova. In the place of its tserkvas that was destroyed a Roman Catholic Church was built. Six tserkvas were taken over by Roman Catholic Church in Mychkivtsi, Polyanchyk, Mychkiv, Berezhnytsya Horishnya, Horyanka and Zabriddya. Nonexisting tserkvas were analyzed in the Solyna commune with their surrounding landscape. It is proved that these all are original and represent a wide diversity of architecture and symbols of Ukrainian religious architecture, showing the Ukrainian character that harmonizes the area and landscape. The article discusses the perspective of maintaining and reconstructing tserkvas, as well as manner and methods of studying this issue.
\end{abstract}

Key words: sacred landscape, Ukrainian tserkva, Solyna commune.

DOI: https://doi.org/10.17721/2413-7154/2017.78.11-17

UDC: $911.2+911.3$

\section{НЕІСНУЮЧІ ЦЕРКВИ ЯК УКРАЇНСЬКА КУЛЬТУРНА СПАДЩИНА У САКРАЛЬНОМУ ЛАНДШАФТІ ГМІНИ СОЛИНА}

\author{
'Ганна КОЗАК, ${ }^{2}$ Ігор КОЗАК \\ 1,2Люблінський католицький університет ім. Иоана Павла II, Польща \\ 'hannakozak@kul.lublin.pl
}

\begin{abstract}
Анотація: Стаття присвячена неіснуючим 20 українським церквам гміни Солина Підкарпатського воєводства на польсько-українському прикордонні. Подана історія та архітектурні риси церков у контексті поселень гміни. Показано, що усі являються ідентичними із широким архітектурним різноманіттям і символами української національної церкви і представляють український характер гміни Солина. Після масової депортації українського населення із їх етнічних земель церкви перестали виконувати релігійну, культурну та націоутворюючу роль, а сакральний ландшафт втратив своє значення. Неіснуючі церкви (20) займають майже $100 \%$ усіх церков на досліджуваній території. У статті показана специфіка українського дерев'яного та кам'яного церковного зодчества. Дві церкви були знищені у роках 1945-1947 у селах Тискова (Tyskowa) і Радева (Radziejowa). Чотири церкви були знищені після 1945-1947 років у селах Буковець (Bukowiec), Студенне (Studenne), Ральське (Rajskie) і Бережниця Долішня (Bereżnica Niżna). П'ять церков були розібрані у післявоєнний період у місцевостях: Солина (Solina), Березка (Berezka), Городок (Horodek), Терка (Terka) і Вовковия (Wołkowyja). Три церкви були знищені у післявоєнний період у селі Завіз (Zawóz), Бібрка (Bóbrka) і Воля Матясова (Wola Matiaszowa). На їх місці збудовано римо-католицькі костели. Шість церков були перейняті римо-католицькими костелами у місцевостях: Мичківці (Myczkówce), Полянчик (Polanczyk), Мичків (Myczków), Бережниця Горішня (Bereżnica Wyżna), Горянка (Górzanka) та Забріддя (Zabrodzie). Неіснуючі церкви були проаналізовані у гміні Солина разом із навколишнім ландшафтом. У статті наголошено на шляхах подальших наукових досліджень із проблематики та важливості відтворення знищених церков із застосуванням тривимірних технологій.
\end{abstract}

Ключові слова: сакральний ландшафт, українська церква, гміна Солина.

DOI: https://doi.org/10.17721/2413-7154/2017.78.11-17

UDC: $911.2+911.3$

(C) H. Kozak, I. Kozak 
Formulation of the scientific problem. Ukrainian tserkva is a unique and inimitable wooden tserkva that has no analogues in the world. [7, 9, 13, 14]. Tserkva constitutes not only a physical object of religious cult, but also a center of community in which tserkva is located. This religious monument delivers the spirituality of the surrounding world order. Modern communities still continue the practice of settling around their churches or other temples, which also applies to Ukrainian tserkvas. Practice of constructing wooden Ukrainian tserkvas was officially introduced before Christianity. The masters preserved the composition and architectural forms, bequeathed by their ancestors in other to continue the tradition [9].

Analysis of last research of the problem. Scientific research concerns origins of Ukrainian tserkvas - those existing, vanishing and non-existing ones [2, 3, 9, 14], its construction and architecture [2, 6, 13, 14], the development in terms of their form [13] and modern types $[7,13,14]$, tserkvas in different Ukrainian eparchies and its ethnic territories $[1,2,6,12,13]$. Moreover, there was conducted a $3 \mathrm{D}$ reconstruction of Ukrainian wooden tserkvas in their sacral landscape of borderland [4]. However, there has been little research over the Solyna commune.

Purpose and the main tasks. The purpose of this article is to identify nonexisting tserkvas in Solyna commune in the landscape of the Polish-Ukrainian borderland.

Objects and methods. We analyzed 20 nonexisting tserkvas in Solyna commune, based on archive materials, historical photography, field research and documentation of tserkvas in their location. Ukrainian wooden tserkvas were usually built on the basis of crucifix form - usually centric, with five or nine "zrubs", called the technique of "zrub" and "zalom" [7, 9, 13]. Proportions of tserkvas height and length differ, depending on the region of Ukraine. The tserkva's height equals its length in the Podillya and Naddnipryanshchyna. In Chernihiv, Boyko and Slobozhanshchyna region the height is greater than their length. In Halychyna and Volyn region the height is smaller than the length $[7,9,12,13,14]$. Tserkva is considered to be a central part of sacral landscape, being the center of spirituality and faith [14].

Main material. Solyna commune was a part of the west Halychyna in Beskydy of Carpathians region. Population of this region consisted mainly (Fig. 1) of Ukrainians [1, 5, 8, 9, 10]. Consequently, Ukrainians formed the historical traditional landscape with tserkva in its center.

Tserkva's architecture has never been separated from outer environment. The structural design is actually within its landscape, reflecting some of its elements by the structure. The natural color of the beams, wall sheathing, wood tile (in Ukrainian it is called "hont") - all these elements link tserkva with the surrounding landscape, not only due to its building material, but also the similarity to the forms of living trees and their crowns. Baroque domes of tserkva, with crosses on its top, provide gentle and harmonious transition from architectural volume to surrounding space in the landscape - opened beneath the dome of the sky $[4,14]$.

This cultural landscape became an important element of life of Ukrainians, being a genus loci, transforming into a part of the sacral landscape [1, 13]. After World War II Ukrainian ethnic population that lived in Beskydy region was massively deported from their homeland to the USSR and Western part of Poland [1, 11]. Five villages (Horodok,

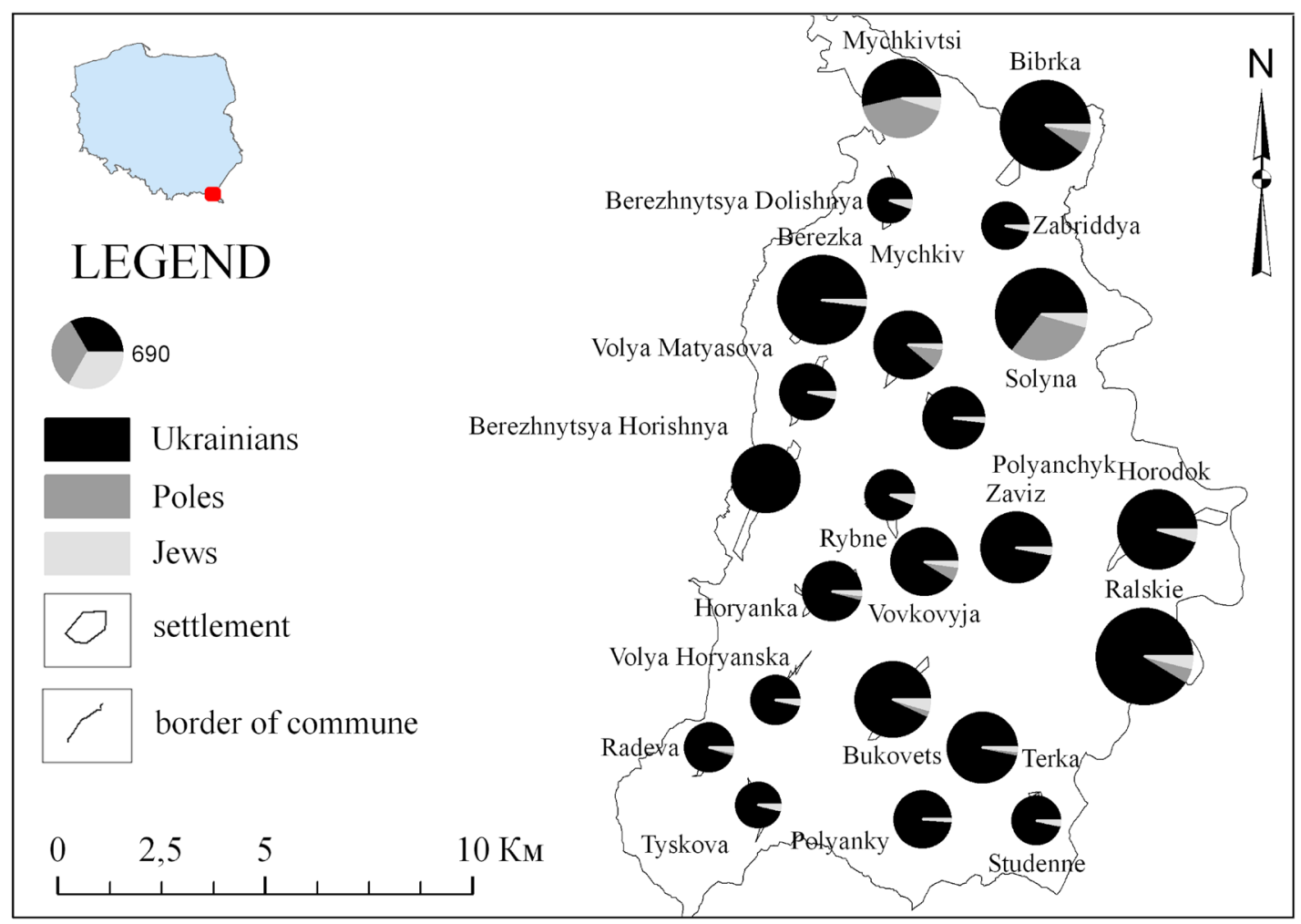

Fig. 1. Settlement distribution in Solyna commune.

Number of Ukrainians, Poles and Jews in the year 1939 according to V. Kubijovyč [5]. 
Studenne, Vovkovyja, Radeva, Tyskova) located in this region disappeared after deportation, called operation „Visla”. In the following villages: Polyanchyk, Berezka, Solyna, Mychkivtsi a traditional village system was destroyed as a result of construction of Solyna reservoir. Tserkvas in these villages were destroyed as well. Cultural and sacral landscape of the villages, with tserkva in its the centre, lost its significance. Tserkva ceased to continue to carry out its sacral role. Usually, there was a cemetery around tserkva, that currently, in cases of a number of villages, is in ruins $[1,3,11,12,13]$.

There was 20 wooden and stone tserkvas in the Solyna commune in such settlements as: Tyskova, Solyna, Zaviz, Mychkivtsi, Bukovets, Polyanchyk, Berezka, Bibrka, Horodok, Terka, Volya Matyasova, Mychkiv, Berezhnytsya Horishnya, Studenne, Vovkovyja, Horyanka, Radeva, Zabriddya, Berezhnytsya Dolishnya, Ralske. As a result, there were 14 tserkvas in Solyna commune that do not exist anymore: tserkva of Archanhel Mychajil from 1700 in Tyskova (destroyed during 1947), tserkva of Mykolaj Chudotvorets from 1810 in Radeva (destroyed during 1945), tserkva of Velykomuchenyk Dmytrij from 1865 in Bukovets (destroyed in 1947), tserkva of Vasylij Velykyj from 1926 in Studenne (destroyed in explosion in 1947), tserkva of Preobrazhennya Hospodnye from 1800 in Solyna (destroyed in 1960 for the reason of constructing Solyna reservoir), tserkva of Strasti Chrysta from 1848 in Horodok (disassembled in 1954 for building purposes), tserkva of Prorok Illya from 1489 in Terka (destroyed in 1957), tserkva of St. Petro and Pavlo from 1833 in Vovkovyja (plundered and destroyed for the reason of constructing Solyna reservoir in 1967), tserkva of Preobrazhennya Hospodnye from 1444 in Berezka (disassembled in 1950 for building purposes), tserkva of Svyata Velykomuchenytsya Paraskeva from 1493 in Ralske (plundered and destroyed after 1947), chapel of Bohorodytsya Opika from 1916 in Berezhnytsya Dolishnya (destroyed after 1947), tserkva of Svyata Velykomuchenytsya Paraskeva from 1850 in Zaviz (destroyed after 1947), tserkva of Velykomuchenyk Hryhorij from 1908 on the place of elder one (disassembled after 1945-1947), tserkva of Pokladennya Ryzy of Mariya Diva from 1760 in Bibrka.

Six tserkvas were taken over by the Roman Catholic Church after 1947: tserkva of Svyatyj Hryhorij from 1815 in Mychkivtsi (taken over in 1979); wooden tserkva of Velykomuchenytsya Presvyata Paraskeva from 1700 in Polyanchyk; tserkva of Uspinnya Materi Bozhoji from 1890 in Mychkiv (taken over in 1977); tserkva of Mykolaj Chudotvorets from 1515 in Berezhnytsya Horishnya (taken over in 1970); tserkva of Svyata Velykomuchenytsya Paraskeva from 1559 in Horyanka (taken over in 1948); stone tserkva of Petro and Pavlo from 1912 in Zabriddya (taken over after 1947).

Firstly, in the article there were discussed nonexisting tserkvas that may be found on illustrations. These are tserkvas in such villages as: Tyskova, Bukovets, Berezhnytsya Dolishnya, Vovkovyya, Terka, Solyna, Horyanka, Berezhnytsya Horishnya, Mychkivtsi and Zabriddya.

In 1700 there was a parish and tserkva of Archangel Myhayil in Tyskova (Fig. 2a). In 1939 in Tyskova there lived 270 Ukrainians and 10 Jews. In 1947 year village and tserkva of Archangel Myhayil in Tyskova were destroyed. After the year 1947 cemetery tombstones were destroyed, there remained only old trees.

Bukovets was an Ukrainian village in Solyna commune. In the village there lived 725 Ukrainians, 20 Poles and 35 Jews [5, 10]. Tserkva of St. Velykomuchenyk Dmytrij (Fig. 2b) from 1865 was the second in Bukovets. There was a stone bell tower also. Tserkva was destroyed after 1947.

Filial chapel of Bohorodytsya Opika was built in 1916 in the village Berezhnytsya Dolishnya (Bereznica Niżna). Berezhnytsya Dolishnya was an Ukrainian village. In 1939 there are lived 255 Ukrainians and 15 Jews [5, 10]. After the year 1947, the chapel in Berezhnytsya Dolishnya was plundered. Now it is in ruins (Fig. 3a).
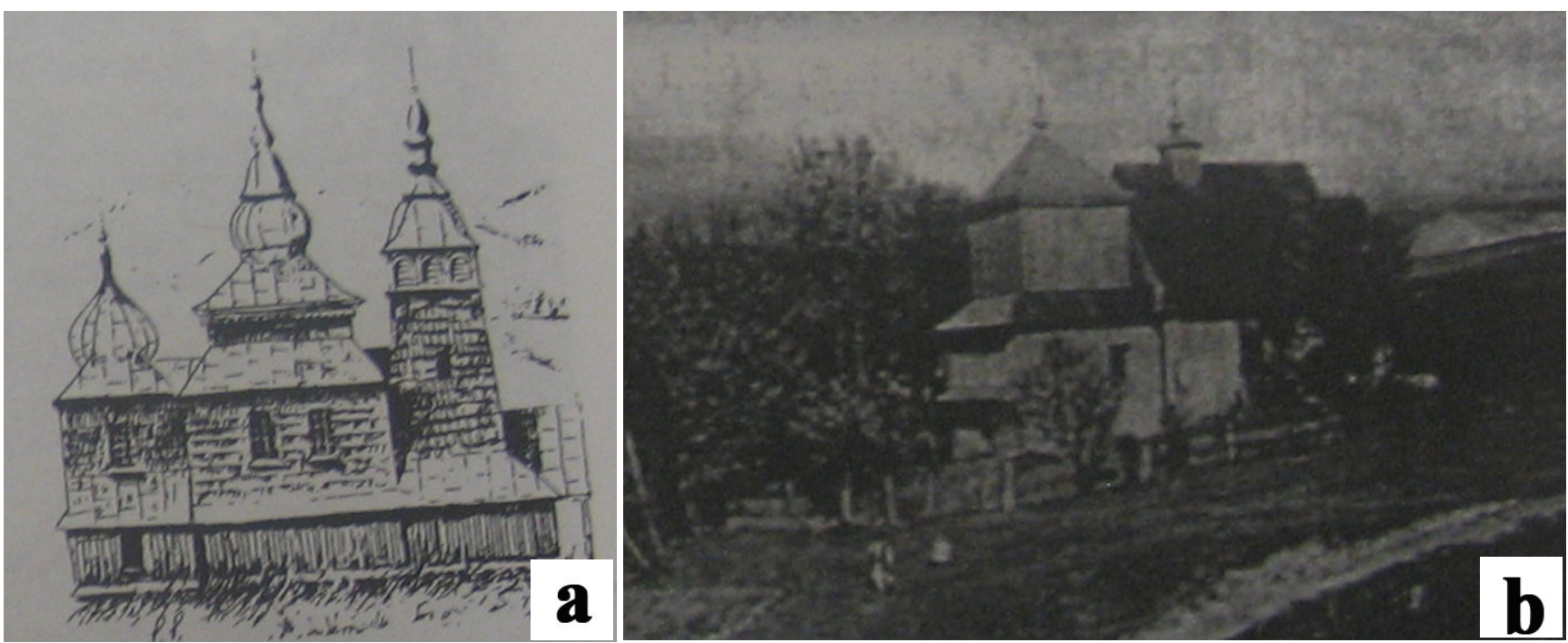

Fig. 2. Non-existing wooden tserkvas in Solyna commune: a) of Archanhel Myhayil (from 1700) with three-sector form and "three dome" structure in Tyskova (destroyed in 1947), b) of St. Velykomuchenyk Dmytrij (from 1865) with three-sector form and "one dome" structure in Bukovets (destroyed after 1947). 
Ukrainian tserkva of Apostol Petro and Pavlo from 1833 was located in Vovkovyja (Wołkowyja). There were 565 Ukrainians, 40 Poles and 15 Jews living in Vovkovyya in 1939 [5, 10]. After 1945 there were no Ukrainians in Vovkovyya. In 1967 tserkva and the bell tower from 1900 were plundered and destroyed (Fig. 3b) for the reason of constructing a Solyna reservoir. 7 icon were removed from tserkva to Syanik museum. Icon of Bohorodytsya was removed to the Peremyshl. In the cemetery near the tserkva remained only one grave of paroch Mychajlo Rostovych. Rybne was a filial of Vovkovyja parish.
Terka was a Ukrainian village till the year 1947. In 1939 there lived 660 Ukrainians, 10 Poles and 10 Jews $[5,10]$. Tserkva of Illya Prorok in Terka was built together with a bell tower in 1489 on the hill on the territory of the monastery. New tserkva with the same name was built in 1771 (Fig. 4a) with three-sector form and "three domes" structure, then another one in 1911 with a stone chapel. After 1947 tserkva was disassembled. At present time there are ruins of the cemetery near the tserkva without some graves.

Wooden tserkva of Preobrazhennya Hospodnye and bell tower was built in 1800 (Fig. 4b) in the place
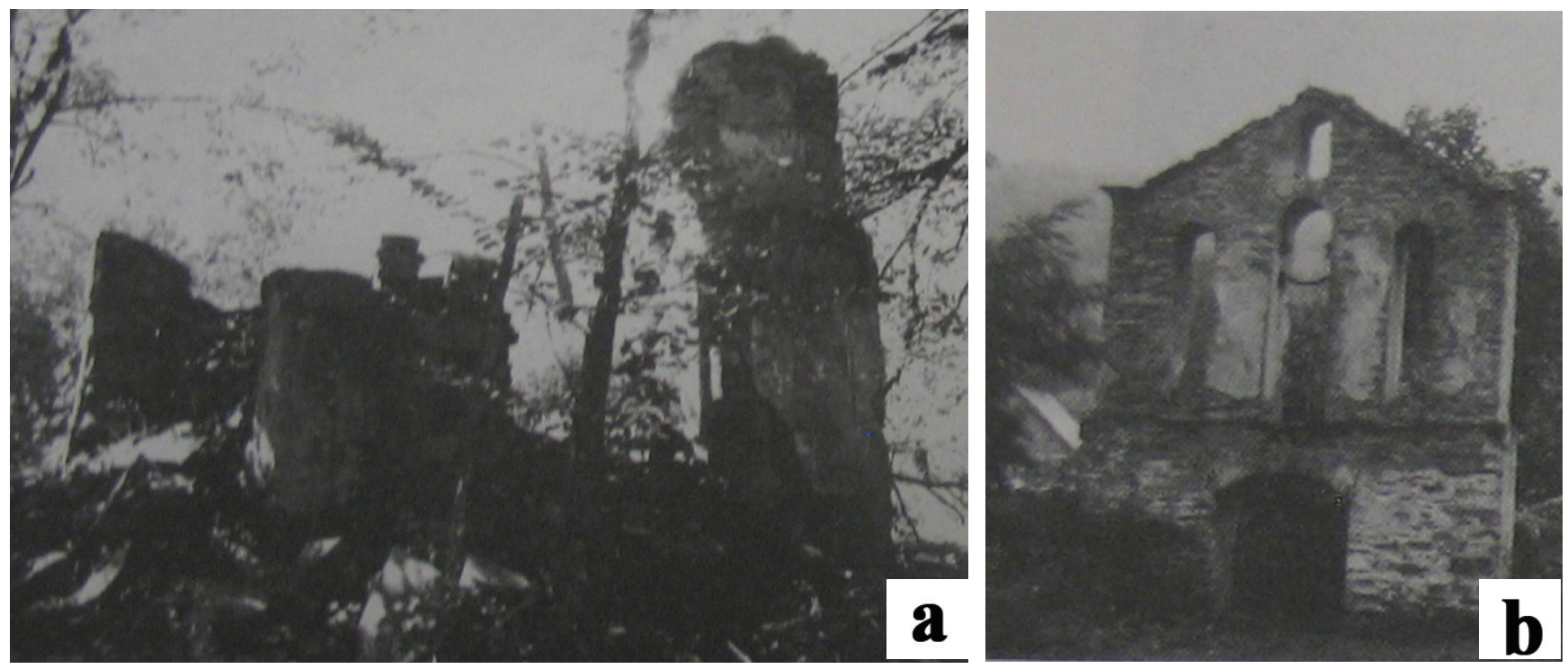

Fig. 3. Ruins of non-existing stone tserkvas destroyed after 1947 in Solyna commune: a) of Bohorodytsya Opika from 1916 in Berezhnytsya Dolishnya, b) of Apostol Petro and Pavlo from 1833 in Vovkovyja (destroyed for the reason of constructing a Solyna reservoir).
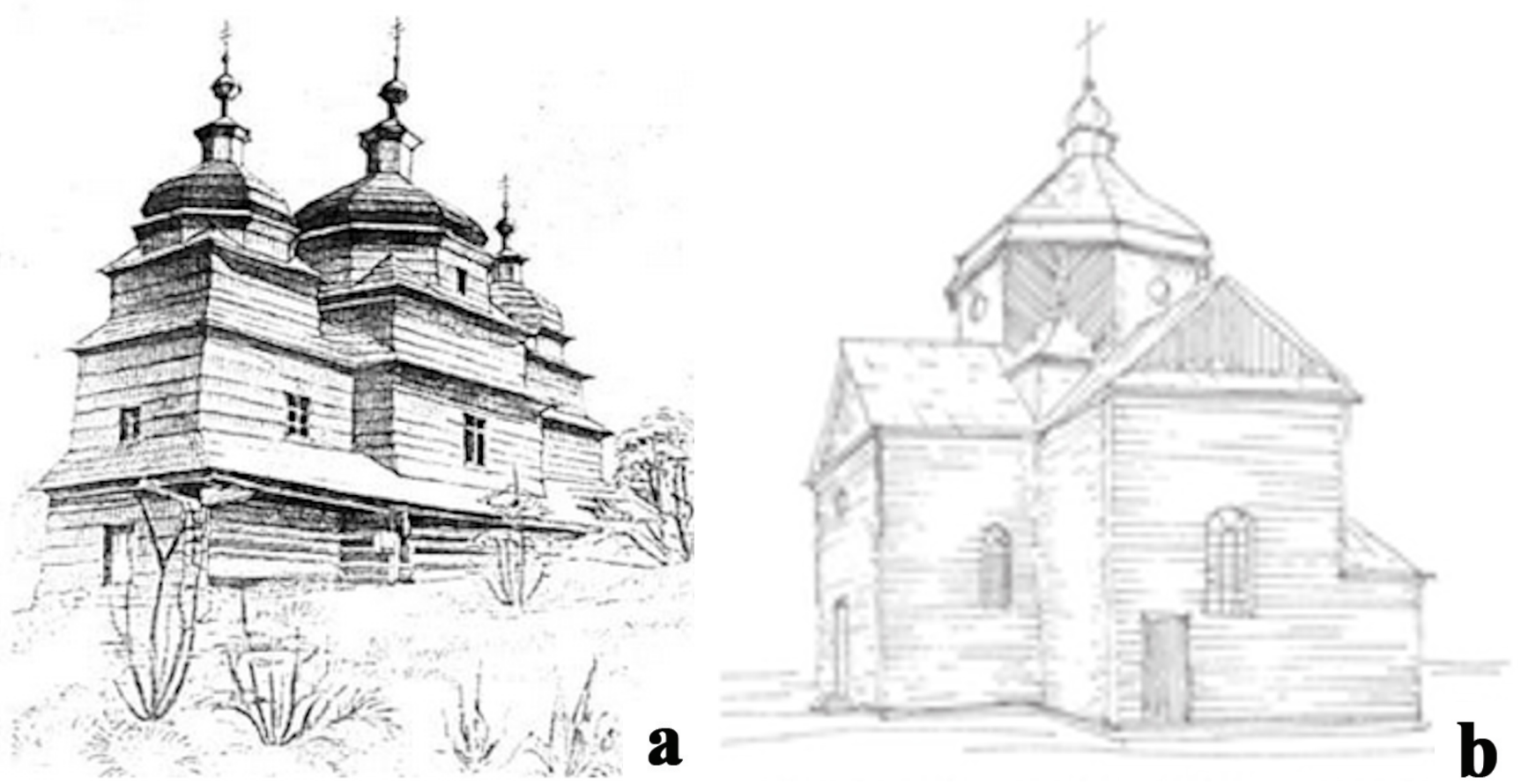

Fig. 4. Non-existing wooden tserkvas in “Bojko Ukrainian” style in Solyna commune: a) of Illya Prorok from 1771) with three-sector form and "three dome" structure in Terka (disassembled in 1960); b) of Preobrazhennya Hospodnye from 1800 with three-sector form and "one dome" structure in Solyna (disassembled in 1960 for the reason of constructing a Solyna reservoir). 
of previous one in the village of Solyna (Solina). In Solyna there lived 740 Ukrainians, 360 Poles and 50 Jews in the year 1939 [5, 10]. After the year 1947 there were no Ukrainians in the village. Wooden tserkva of Preobrazhennya Hospodnye was disassembled in 1960 for the reason of constructing a Solyna reservoir.

In the year 1559 there had already existed a tserkva of Svyata Velykomuchenytsya Paraskeva (Fig. 5a) in Horyanka (Górzanka). New tserkva with the same name was built in 1744 Near that tserkva there was a wooden bell tower with two bells and a cemetery with devastated graves. In 1939 there lived 460 Ukrainians, 10 Poles and 10 Jews. After 1947 tserkva was taken over by Roman Catholic church in 1948.

Berezhnytsya Horishnya (Bereznitsa Wyżna) was a large Ukrainian parish and village in 1772 . Tserkva of Mykolaj Chudotvorets had already existed in the year 1515. A new one with a wood bell tower were built in 1830 (Fig. 5b) adding a bell in 1868. A large stone chapel was built in 1908. In 1939 there lived 625 Ukrainians and 5 Jews in Bereżnytsya Horishnya $[5,10]$. Tserkva in Berezhnytsya Horishnya was plandered in 1960's. In 1970 tserkva of Mykolaj Chudotvorets was taken over by Roman Catholic church.

In 1815 there was a tserkva of Svyatyj Hryhorij (Fig. 6a) in Mychkivtsi (Myczkowce). In 1910 new tserkva with the same name was built. A stone chapel from 1858 in Mychkivtsi is a symbol for Ukrainians of abolishing serfdom in 1848. In the year 1939 there were 450 Ukrainians, 350 Poles and 40 Jews living in Mychkivtsi [5, 10]. After 1947 tserkva was plundered. From 1979 tserkva of Svyatyj Hryhorij was taken over by Roman Catholic church.

Zabriddya (Zabrodzie) was an Ukrainian village and parish till the year 1947. In 1939 there lived 290 Ukrainians and 10 Jews $[5,10]$. Stone tserkva of Apostol Petro and Pavlo was built in 1912 (Fig. 6b). It was not the first one. Tserkva of Apostol Petro and Pavlo was taken over by Roman Catholic church after the 1947.
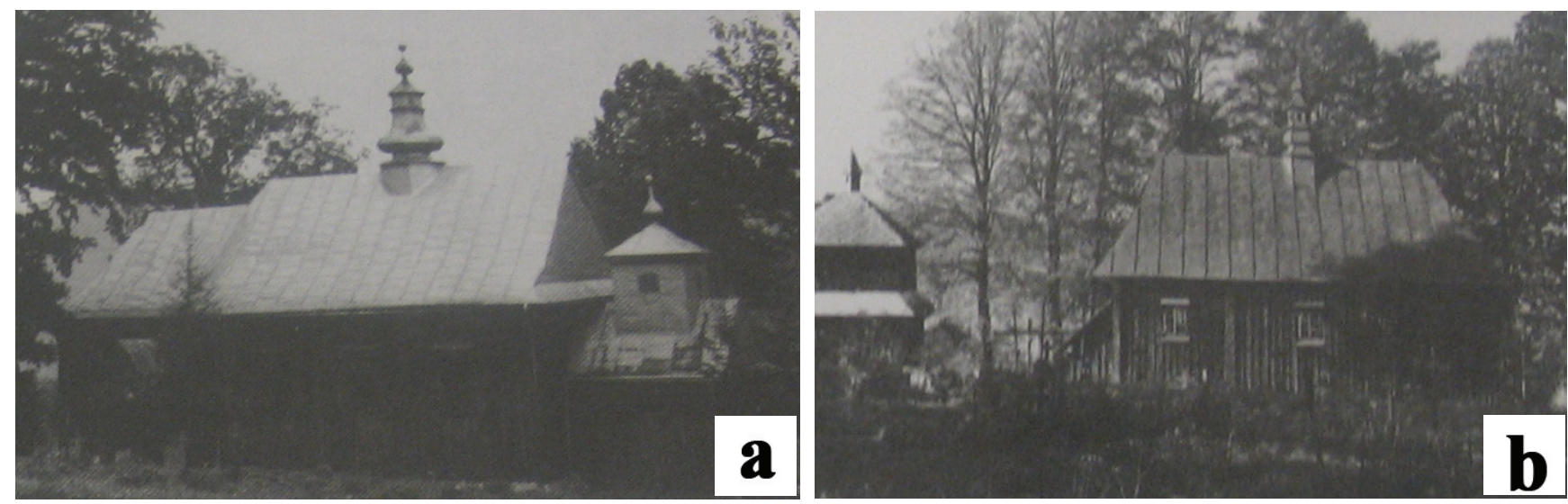

Fig. 5. Non-existing wooden tserkvas with the bell towers taken over by Roman Catholic church after 1947 in Solyna commune: a) of Svyata Velykomuchenytsya Paraskeva from 1559 in Horyanka, built in three-sector form;

b) tserkva of Mykolay Chudotvorets from 1830 in Berezhnytsya Horishnya, built in three-sector form.
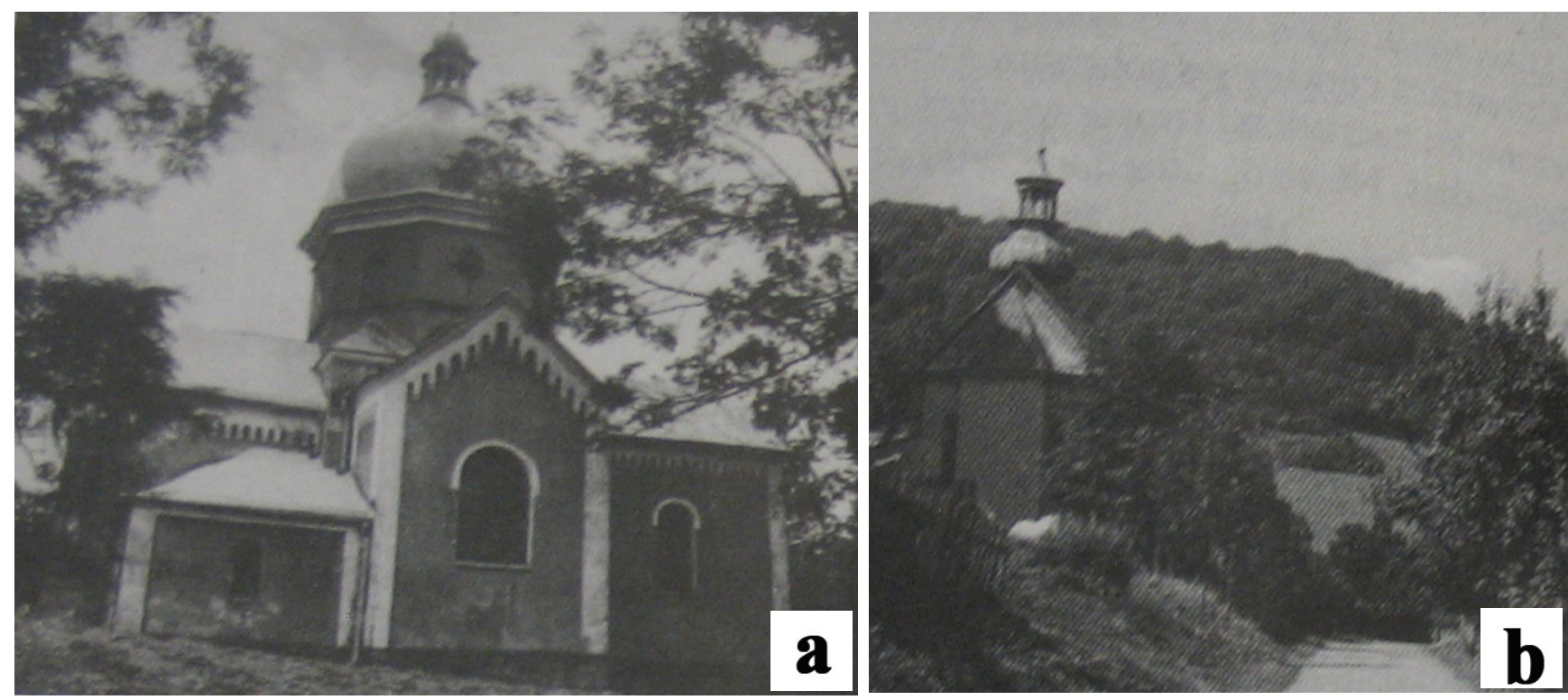

Fig. 6. Non-existing stone tserkvas in "Ukrainian Byzantine" style taken over by Roman Catholic church after 1947 in Solyna commune: a) of Svyatyj Hryhorij from 1815 in Mychkivtsi; b) of Apostol Petro and Pavlo from 1912 in Zabriddya. 
Unfortunately, for the remaining 10 tserkvas no illustrations were found. That may be a purpose of future research. These tserkvas, which were not documented on illustrations, were located in the following villages: Zaviz, Radeva, Volya Matyasova, Berezka, Horodok, Studenne, Mychkiv, Polyanchyk, Bibrka, Ralske.

Wooden tserkva and parish of Mykolaj Chudotvorets was functioning in Radeva (Radziejowa) before 1785. In 1900 there was built a new tserkva with the same name. Radeva was an ancient Ukrainian village till the year 1947. According to the statistics, in 1939 there lived 315 Ukrainians, 5 Poles and 10 Jews. The village and tserkva in it were destroyed (burnt) in 1947.

Mychkiv (Myczków) was a large and ancient Ukrainian village and parish till the year 1947. In 1939 there lived 560 Ukrainians, 60 Poles and 10 Jews [5, 10]. Wooden tserkva of Uspinnya of Matir Bozha was built in 1890. Tserkva of Uspinnya of Matir Bozha was taken over by Roman Catholic church in 1977.

In 1926, in the place of older tserkva in the village Studenne, a new one of Archangel Myhayil was built. As for the year 1939 in Studenne there lived 310 Ukrainians and 10 Jews [5, 10]. In 1947 tserkva was destroyed. A chapel from 1873 which is a symbol of abolishing serfdom in 1848 with a spring was destroyed in the same time also. At present time, there are only ruins of the cemetery near the tserkva.

Ralske (Rajskie) was an old Ukrainian village in Solyna commune. In 1939 there lived 1170 Ukrainians, 60 Poles and 50 Jews. Their tserkva of Svyata Velykomuchenytsya Paraskeva (Fig. 5a) was built in 1845 in the place of previous one from 1493 with two-sector form and "one dome" structure. It was restored in 1898. In 1947 tserkva was plundered. From the year 1970 it is in ruins.

Berezka was a large and ancient Ukrainian village and parish till the year 1947. In 1939 there lived 1055 Ukrainians, 5 Poles and 20 Jews [5, 10]. Wooden tserkva of Preobrazhennya Hospodnye was built in 1444. New large stone tserkva in Ukrainian Byzantine style was built in 1835. Tserkva of Preobrazhennya Hospodnye was disassembled in 1950.

Horodok (Horodek) was a large and ancient Ukrainian village. In 1939 there lived 815 Ukrainians, 5 Poles and 40 Jews [5, 10]. After 1947 the village was destroyed and tserkva of Strasti Chrysta (from 1848) was disassembled in 1954.

In 1850 there was a tserkva of Svyata Velykomuchenytsya Paraskeva in Zaviz (Zawóz). In 1870 tserkva was renovated. In the year 1939 there were 655 Ukrainians, 5 Poles and 20 Jews living in Zaviz [5, 10]. In 1947 tserkva was plundered and destroyed. A stone chapel of Bohorodytsya with a spring from 1800 was also destroyed. Afterwards, in the place of that tserkva, a Roman Catholic church was built.

Volya Matyasova (Wola Matiaszowa) was a large Ukrainian parish and village in 1900. Tserkva of Velykomuchenyk Hryhorij had already existed in the year 1750. A new one was built in 1908. In 1939 there lived 690 Ukrainians, 10 Poles and 20 Jews in
Volya Matyasova [5, 10]. Tserkva in Volya Matyasova was plandered in 1950's. In 1983 in the place of that tserkva, a Roman Catholic church was built.

In the year 1760 there had already existed a tserkva of Pokladennya Ryzy of Mariya Diva in Bibrka (Bóbrka). New tserkva with the same name was built in 1937. In 1848 in Bibrka was built a stone chapel which is a symbol of abolishing serfdom in 1848. In 1939 there lived 1000 Ukrainians, 85 Poles and 25 Jews in Bibrka [5, 10]. It was an Ukrainian village. After 1947 tserkva was destroyed. In 1957 in the place of that tserkva, a Roman Catholic church was built.

In the year 1700 there existed tserkva of Svyata Velykomuchenytsya Paraskeva and a bell tower in Polyanchyk. A chapel was built in 1909. There was a holy spring in the chapel. Polyanchyk was a large Ukrainian village. In 1939 there lived 515 Ukrainians, 5 Poles and 10 Jews. After 1947 tserkva of Svyata Velykomuchenytsya Paraskeva and chapel were taken over by Roman Catholic church in 1948. The icon of Bohorodytsya and "vivtar" were removed to the Roman Catholic Church in Polyanchyk from the Lopyanka Ukrainian tserkva. Afterwards the icon of Bohorodytsya was replaced by its copy.

In many cases names of villages were distorted from Ukrainian language: Zaviz (ukr. Завіз) into Zawóz; Vovkovyjya (ukr. Вовковия) into Wołkowyja; Horyanka (ukr. Горянка) into Górzanka; Berezhnytsya Horishnya (ukr. Бережниця Горішня) into Bereżnica Wyżna; Radeva (ukr. Радева) into Radziejowa; Bukovets (ukr. Буковець) into Bukowiec; Volya Horyanska (ukr. Воля Горянська) into Wola Górzańska; Volya Matyasova (ukr. Воля Матясова) into Wola Matiaszowa; Berezhnytsya Dolishnya (ukr. Бережниця Долішня) into Bereżnica Niżna; Mychkivtsi (ukr. Мичківці) into Mychkowce; Solyna (ukr. Солина) into Solina; Horodok (ukr. Городок) into Horodek; Mychkiv (ukr. Мичків) into Myczków; Bibrka (ukr. Бібрка) into Bóbrka; Ralske (ukr. Ральське) into Rajskie; Zabriddya (ukr. Забріддя) into Zabrodzie.

Each of the already non-existing tserkvas, located in area of Solyna commune, is Ukrainian national tserkva, constituting Ukrainian national heritage, within the sacred landscape of Polish-Ukrainian borderland [1, 3, 10, 11, 12].

Conclusions. Each tserkva that was examined in Solyna commune is a unique element of national heritage and presents a wide variety of architectural techniques, as well as symbols of Ukrainian religious cult.

Tserkvas were developed in common Ukrainian traditions on the Polish-Ukrainian borderland, including the Solyna commune. "Byzantine Ukrainian" style and "Boyko Ukrainian" style tserkvas dominated in the region. Wooden construction was quietly characteristic due to its features - mainly because of the fact that three domes and cupola usually covered their tops. Tserkvas, built in 18-19th centuries, are considered to be a proof of Ukrainian Bizantine style. Tserkvas that remained till these days are a relic of Ukrainian 
culture, art and architecture. World War II and mass deportation of Ukrainians from their ethnic territories, that took place after the War, had an enormous impact on this region. Tserkvas were destroyed. This practice led to the disappearance of tserkvas from this landscape. As a result, the traditional landscape of original significance was completely lost. Mass deportation of Ukrainians deprived villages and the whole region of its indigenous inhabitants. Tserkvas had a similar fate as Ukrainians and these that remained till present days are considered to be the evidence of Ukrainian character in the region and its landscape.

The study has shown that Ukrainian tserkvas, not only those located within the analyzed region, require an important reconstruction works, since they are losing their original significance. It is highly perspective to reconstruct these tserkvas and prepare them for the purposes of 3D visualization in order to conduct a detailed documentation.

\section{References:}

1. Apokryf Ruski, Otwarte ukraińskie zasoby naukowe, 2010. [Electronic source]. Access mode: http//www. apokryfruski.org/. [Accessed 12.03.2017]

2. Blazchejiwskyj D. Historical Schematism of the Ukrainian Catholic Church. An. OSBM section, Rome, 1988, Vol. 45,1318 p.

3. Iwanusiw O. Church in Ruins: The demise of Ukrainian churches in the eparchy of Peremyshl. St. Catharines: St. Sophia $1986,-354$ c.

4. Kozak H. Three-dimension modeling in reconstruction of old woodem church in Ukraine. Kultura i Historia 2012, vol. 21. $217 \mathrm{p}$

5. Kubijovyč V. Ethnic groups of the South-Western Ukraine (Galyčyna-Galicia) 1.1.1939. München: Logos, 1983,

6. Saładiak A. Pamiatki i zabytki kultury ukraińskiej w Polsce. Warszawa, 1993, 511 p.

7. Večerskyj V. Uktä̈śski derewậni hramy [Ukrainian wooden churches]. Kyiv: Naš čas, 2008, 270 p. (In Ukrainian).

8. Hruševśkyj M. Džerela do istoriji Ukrajiny-Rusy [Sources of Ukraine-Ruś history]. Lviv, 1900, T.3, 272 p. (In Ukrainian).

9. Drahan M. Ukraïnśki derevâni tserkvy. Geneza i rozvij form [Ukrainian wooden churches. Geneza and form development]. Lviv, 1937, 12 p. (In Ukrainian).

10. Kubijovyč V. Lûdnist z ukrä̈nśkô̂ movoû v Halyčyni. Karta. Encyklopediậ ukrä̈noznavstva [Ukrainian population in Halyčyna. Map. Ukrainian encyclopedia]. Lviv: NTŠ, 1993, 349 p. (In Ukrainian).

10. Misylo J. Hrekokatolytśka tserkva u Pol’či (1944-1947) [Greek Catholic tserkva in Poland]. Varšavśki ukrä̈noznavči zošyty, 1989, pp. 207-220. (In Ukrainian).

12. Slobodận V. Katalog isnuûčyh derevậnyh tserkov Ukraïny z ukraïnśkyh etničnyh zemel' [Catalog of existing Ukrainian wooden tserkvas in Ukrainian ethnic area]. Visnyk instytutu "Ukrzahidrestavraciạ", 1996, N. 4, pp. 74-159. (In Ukrainian).

13. Taranuščenko S. Monumental’na derevậna arhitektura LivoberežnoïUkraïny [Monunental wooden architecture of the Left-Bank Ukraine]. Kyiv: 1976, 333 p. (In Ukrainian).

14. Ščerbakivśkyj V. Derevậni tserkvy v Ukrä̈ni ta ïh typy [Wooden tserkvas in Ukraine and its types]. Lviv, 1906. (In Ukrainian). 